\author{
Sylwia PIEŃKOWSKA-KAMIENIECKA* \\ Joanna RUTECKA ${ }^{* *}$
}

\title{
PROBLEMATYKA DECYZJI I KOMPETENCJI FINANSOWYCH OSÓB STARSZYCH W UJĘCIU EKONOMICZNYM
}

Posiadanie odpowiednich kompetencji finansowych przez osoby starsze jest problemem istotnym. Seniorzy stanowią bowiem, z racji przekształceń w strukturze demograficznej, coraz liczniejszą grupę konsumentów i potencjalnie istotnych inwestorów na rynku finansowym. Podejmowane przez nich decyzje finansowe nie zawsze odpowiadają faktycznym potrzebom, co wynika z niedostatków wiedzy finansowej, spadku możliwości analitycznych oraz szybkich zmian dotyczących funkcjonowania rynków finansowych. Analiza poziomu wiedzy i kompetencji finansowych w wybranych krajach potwierdziła, iż poziom ten zmienia się wraz z wiekiem. Osoby po 60 roku życia borykają się z problemami dotyczącymi oceny i porównania oferty dostępnej na rynku finansowym, a mając świadomość własnych niedostatków decydują się na nabycie produktów dobrze znanych.

Słowa kluczowe: decyzje finansowe, kompetencje finansowe, edukacja finansowa, osoby starsze

\section{WSTĘP}

Demograficzne starzenie się społeczeństwa jest rezultatem znacznych zmian ekonomicznych, społecznych i medycznych, które stwarzają możliwość dłuższego życia w lepszych warunkach, niż miało to miejsce kiedykolwiek w przeszłości. Jest to równocześnie jedno $\mathrm{z}$ wyzwań, $\mathrm{z}$ jakimi wiele krajów będzie musiało zmierzyć się w przyszłości. Obniżający się spadek dzietności, zwiększający się odsetek osób z tzw. powojennego wyżu urodzeniowego (będących obecnie w wieku 45-65 lat)

\footnotetext{
* Uniwersytet Warmińsko-Mazurski w Olsztynie, Wydział Nauk Ekonomicznych, Katedra Polityki Społecznej i Ubezpieczeń.

${ }^{* *}$ Szkoła Główna Handlowa w Warszawie, Kolegium Analiz Ekonomicznych, Instytut Statystyki i Demografii.
} 
przy wydłużającym się trwaniu życia powodują, że w rezultacie w ujęciu ekonomicznym liczba ludności Unii Europejskiej w wieku produkcyjnym (15-64 lata) obniży się o $48 \mathrm{mln}$ do $2050 \mathrm{r}$., a wskaźnik zależności wiekowej według prognoz Komisji Europejskiej podwoi się i wyniesie 51\% [European Commission 2006, s. 5]. Takie tendencje wywołują implikacje dla systemów emerytalnych i samego społeczeństwa, które poprzez dokonywane wybory inwestycyjne i oszczędnościowe wpływa na pożądany przez siebie stan bezpieczeństwa finansowego.

Obecnie w wielu uprzemysłowionych krajach świata społeczeństwo jest w coraz większym stopniu odpowiedzialne za zapewnienie sobie wyższego standardu życia w okresie po zakończeniu aktywności zawodowej. Wynika to z przeprowadzonych reform emerytalnych, które często zakładały wprowadzenie formuły zdefiniowanej składki lub innych parametrów ściśle powiązanych ze wskaźnikami demograficznymi, przenosząc na przyszłych emerytów część ryzyk związanych z funkcjonowaniem zabezpieczenia społecznego. Podczas, gdy w Polsce do końca 1998 r. przyszli emeryci polegali wyłącznie na publicznym systemie zabezpieczenia emerytalnego organizowanym w ramach formuły zdefiniowanego świadczenia, od $1999 \mathrm{r}$. system emerytalny oparty został na trzech filarach, gdzie podstawowym narzędziem zastosowanym zarówno w systemie obowiązkowym, jak i dobrowolnym, są indywidualne konta emerytalne funkcjonujące na zasadzie zdefiniowanej składki.

Przejście w kierunku systemu DC zwiększa odpowiedzialność danej jednostki za jej decyzje w zakresie oszczędzania, inwestowania, a później korzystania ze zgromadzonych środków w okresie emerytalnym. W rezultacie, obecnie oszczędzający $w$ ramach podsystemu zdefiniowanej składki są bezpośrednio i natychmiast narażeni na ryzyka związane $\mathrm{z}$ funkcjonowaniem rynku finansowego - ich bezpieczeństwo finansowe $w$ okresie emerytalnym będzie zatem zależeć od ich indywidualnych wyborów, dokonywanych w oparciu o posiadane kompetencje finansowe [Lusardi 2012]. Ma to szczególne znaczenie w sytuacji, gdy rynek finansowy jest coraz większym wyzwaniem dla wielu członków społeczeństwa. Wpływa na to mnogość, różnorodność i wysoki poziom skomplikowania dostępnych na rynku opcji inwestycyjnych, które z założenia, poprzez właściwe wybory inwestycyjne, mają zapewnić wyższy standard życia i bezpieczeństwo finansowe danej jednostki niezależnie od jej wieku.

Celem artykułu jest analiza poziomu wiedzy finansowej i kompetencji finansowych osób starszych oraz zwrócenie uwagi na wybrane aspekty towarzyszące podejmowaniu przez nie decyzji inwestycyjnych.

\section{WIEDZA I KOMPETENCJE FINANSOWE}

Zagadnienie kompetencji finansowych jest szerokie. Obejmuje świadomość $i$ wiedzę finansową na temat produktów $i$ instytucji finansowych, jak również zdolności finansowe, rozumiane jako umiejętność planowania finansowego i zarządza- 
nia posiadanymi środkami pieniężnymi. L. Xu i B. Zia wskazują również na odmienne implikacje kompetencji finansowych $\mathrm{w}$ zależności od poziomu zamożności danego kraju. W krajach o wysokim dochodzie są one postrzegane $\mathrm{w}$ aspekcie ochrony konsumenta (zwłaszcza w czasach kryzysu finansowego), której podstawowym celem jest wyposażenie jednostki w umiejętność analizy skomplikowanych produktów finansowych, takich jak produkty emerytalne i kredyty hipoteczne, służące poprawie standardu życia na emeryturze. $Z$ kolei w krajach o niskim dochodzie, gdzie skomplikowane produkty finansowe są dostępne tylko dla niewielkiego odsetka populacji, celem działań zwiększających kompetencje finansowe jest poprawa dostępu do usług finansowych zwłaszcza wśród mikroprzedsiębiorców. Społeczeństwa tych krajów w znacznym bowiem stopniu polegają na zapewnieniu sobie środków utrzymania $\mathrm{z}$ tytułu prowadzonego przedsiębiorstwa, najczęściej właśnie w skali mikro [Xu i Zia 2012, s. 1-2].

\section{EFEKTYWNY WIEK PODEJMOWANIA DECYZJI FINANSOWYCH}

Decyzje oszczędnościowe i inwestycyjne podejmowane przez członków społeczeństwa są istotne nie tylko $\mathrm{z}$ punktu widzenia bezpieczeństwa finansowego jednostki, ale i wzrostu gospodarczego danego państwa. W związku ze wspomnianymi zmianami demograficznymi, mającymi odzwierciedlenie w zwiększającym się udziale osób starszych w populacji ogółem, osoby te będą w posiadaniu i kontroli coraz większych globalnych zasobów finansowych [Samanez-Larkin, Knutson 2013]. Jak wynika $z$ badań, większość najbardziej znaczących decyzji finansowych nie jest podejmowanych przez osoby w młodszym wieku. Według Fortune 500, tj. rankingu 500 największych amerykańskich firm sklasyfikowanych według przychodów, ich dyrektorzy wykonawczy i finansowi są najczęściej osobami w wieku pomiędzy pięćdziesiątym, a sześćdziesiątym rokiem życia [Samanez-Larkin, s. 30]. $\mathrm{Z}$ analizy błędów towarzyszących podejmowanym decyzjom finansowym w zależności od wieku wynika, że najkorzystniejszym wiekiem je minimalizującym są 53 lata (tab. 1).

W Stanach Zjednoczonych najniższy najefektywniejszy wiek podejmowania decyzji finansowych dotyczył kart kredytowych i tzw. momentu „eureka” (ok. 46 lat). Wiele tamtejszych banków oferuje możliwość przeniesienia salda swojego zadłużenia $\mathrm{z}$ dotychczasowej karty kredytowej na nową kartę, na której odsetki z tytułu zadłużenia są niższe w proponowanym preferencyjnym okresie, wynoszącym od 6 miesięcy do 1 roku lub nawet dłużej. Istota jednakże polega na tym, że zakupy dokonywane nową kartą są oprocentowane zdecydowanie mniej korzystnie, a spłacane zadłużenie najpierw przeznaczane jest na obsługę dotychczasowego (o niższym oprocentowaniu), a dopiero później nowego (o wyższym oprocentowaniu) 
zadłużenia. Najlepszym rozwiązaniem jest w tym przypadku dokonywanie zakupów za pomocą dotychczasowej karty i spłacanie w tym czasie kredytu przeniesionego na nową kartę. Niektórzy orientują się $w$ tej strategii natychmiast, inni po kilku cyklach rozliczeniowych, podczas, gdy pozostali nigdy. $Z$ badań wynika, że po 40. roku życia odsetek osób, które nigdy nie doznały momentu „eureki” wzrasta gwałtownie wraz z wiekiem (od poniżej $30 \%$ w wieku ok. 40 lat do powyżej $50 \%$ w wieku ponad 65 lat), [Agarwal, Driscoll, Gabaix i Laibson 2009, s. 64-65].

Tabela 1. Wiek minimalizujący błędy w decyzjach finansowych

\begin{tabular}{|l|c|c|}
\hline \multicolumn{1}{|c|}{ Wyszczególnienie } & $\begin{array}{c}\text { Wiek najwyższych } \\
\text { kompetencji }\end{array}$ & $\begin{array}{c}\text { Błąd } \\
\text { standardowy }\end{array}$ \\
\hline $\begin{array}{l}\text { Oprocentowanie kredytu zabezpieczonego } \\
\text { na nieruchomości }\end{array}$ & 55,9 & 4,2 \\
\hline $\begin{array}{l}\text { Oprocentowanie linii kredytowej zabezpie- } \\
\text { czonej na nieruchomości }\end{array}$ & 53,3 & 5,2 \\
\hline Tzw. moment „eureka” & 45,8 & 7,9 \\
\hline Oprocentowanie kart kredytowych & 50,3 & 6,0 \\
\hline Oprocentowanie kredytów samochodowych & 49,6 & 5,0 \\
\hline $\begin{array}{l}\text { Oprocentowanie kredytu hipotecznego na } \\
\text { zakup nieruchomości }\end{array}$ & 56,0 & 8,0 \\
\hline $\begin{array}{l}\text { Oprocentowanie kart kredytowych dla małych } \\
\text { firm }\end{array}$ & 61,8 & 7,9 \\
\hline $\begin{array}{l}\text { Opłata za opóźnienie spłaty kredytu na karcie } \\
\text { kredytowej }\end{array}$ & 51,9 & 4,9 \\
\hline $\begin{array}{l}\text { Opłata za przekroczenie limitu na karcie kre- } \\
\text { dytowej }\end{array}$ & 54,0 & 5,0 \\
\hline Opłata za wypłatę gotówki z karty kredytowej & 54,8 & 4,9 \\
\hline Średnia z powyższych badanych przypadków & 53,3 & 4,3 \\
\hline
\end{tabular}

Źródło: [Agarwal, Driscoll, Gabaix i Laibson 2008, s. 26]. Zob. też [Stańko 2013, s. 15].

Podobnie jest $w$ przypadku osób młodych, do ok. 24 roku życia, bowiem jak wynika $\mathrm{z}$ badań Agarwal et al., krzywa występowania błędów towarzyszących podejmowanym decyzjom finansowym przybiera postać litery „U”. Wynika to $\mathrm{z}$ dwóch podstawowych, związanych $\mathrm{z}$ wiekiem, efektów. Osoby relatywnie młodsze mają mniejsze doświadczenie w korzystaniu z produktów finansowych, lecz wykazują się dużymi zdolnościami analitycznymi, natomiast osoby starsze takie zdolności mają wprawdzie ograniczone, jednakże cechują się dużym doświadczeniem [Agarwal, Driscoll, Gabaix i Laibson 2009, s. 73]. W rezultacie krzywa zdolności kognitywnych i uzyskania optymalnych warunków usługi finansowej w odniesieniu do wieku ma kształt "ח" [Agarwal, Driscoll, Gabaix i Laibson 2009, s. 103 oraz Stańko 2013, s. 14]. 


\section{ZMIANA POZIOMU KOMPETENCJI FINANSOWYCH WRAZ Z WIEKIEM}

Wyniki badania przeprowadzonego w Stanach Zjednoczonych przez A. Lusardi i A. Mitchell dostarczyły istotnych informacji na temat poziomu kompetencji finansowych rozpatrywanych $w$ aspekcie trzech podstawowych zagadnień finansowych, tj. rachunku odsetek złożonych, inflacji i dywersyfikacji ryzyka. Okazuje się, że osoby $w$ wieku 25-65 lat $w$ analizowanych obszarach wykazały się przeciętnie o ok. 5 pkt. proc. wyższą wiedzą, niż osoby w wieku poniżej 25 lat i powyżej 65 lat [Xu i Zia 2012, s. 11]. Problem niskich kompetencji finansowych wśród osób w wieku powyżej 60 roku życia dotyczy przede wszystkim kobiet. Zarówno w odniesieniu do procentu składanego, inflacji, jak i dywersyfikacji ryzyka, odsetek udzielanych przez nie dobrych odpowiedzi na powyższe zagadnienia był niższy o 12,3 pkt. proc. niż wśród mężczyzn, natomiast kobiety częściej niż mężczyźni nie potrafiły w ogóle udzielić odpowiedzi - średnio o 11,2 pkt. proc. [Lusardi 2012]. Również z wyników badań zaprezentowanych $\mathrm{w}$, wynika, że kobiety mają mniejszą pewność co do stanu swojej wiedzy i kompetencji finansowych, w związku z czym na zadany problem finansowy częściej niż mężczyźni odpowiadają „nie wiem" [OECD 2013, s. 21]. Największe różnice dotyczyły kwestii związanych z dywersyfikacją ryzyka, gdzie należało wskazać, czy kupno akcji jednej spółki zwykle zapewnia większe bezpieczeństwo niż kupno akcji kilku spółek.

Tabela 2. Poziom kompetencji finansowych osób starszych w odniesieniu do poszczególnych obszarów finansowych (w \% poprawnie udzielonych odpowiedzi)

\begin{tabular}{|l|c|c|c|c|c|}
\hline \multicolumn{1}{|c|}{ Wiek } & Ogółem & $\begin{array}{c}\text { Podstawowa } \\
\text { wiedza } \\
\text { finansowa }\end{array}$ & $\begin{array}{c}\text { Pożyczki } \\
\text { i kredyty }\end{array}$ & Inwestycje & Ubezpieczenia \\
\hline 60-69 lat & 59,12 & 59,18 & 60,52 & 53,02 & 63,77 \\
\hline 70-79 lat & 45,43 & 44,62 & 46,72 & 39,05 & 51,32 \\
\hline 80 lat i więcej & 31,30 & 32,79 & 31,49 & 23,57 & 37,36 \\
\hline
\end{tabular}

Źródło: opracowanie własne na podstawie [Finke, Howe i Huston 2011, s. 23].

Niższe i obniżające się wiedzę i kompetencje finansowe osób starszych zostały też potwierdzone $\mathrm{w}$ badaniach prowadzonych przez Finke at al. [Finke, Howe i Huston 2011].

$\mathrm{Z}$ badań Finke et al. wynikają ciekawe i ważne wnioski, że efektywność podejmowanych decyzji finansowych po ukończeniu 60 roku życia każdego roku spada o $1 \%$, jednakże samoświadomość i pewność samych jednostek w tym zakresie nie wykazuje tendencji malejącej, wręcz przeciwnie. Zwiększająca się pewność co do trafności dokonywanych wyborów, przy obiektywnie obniżających się kompetencjach finansowych wyjaśnia słabe decyzje finansowe osób starszych. 


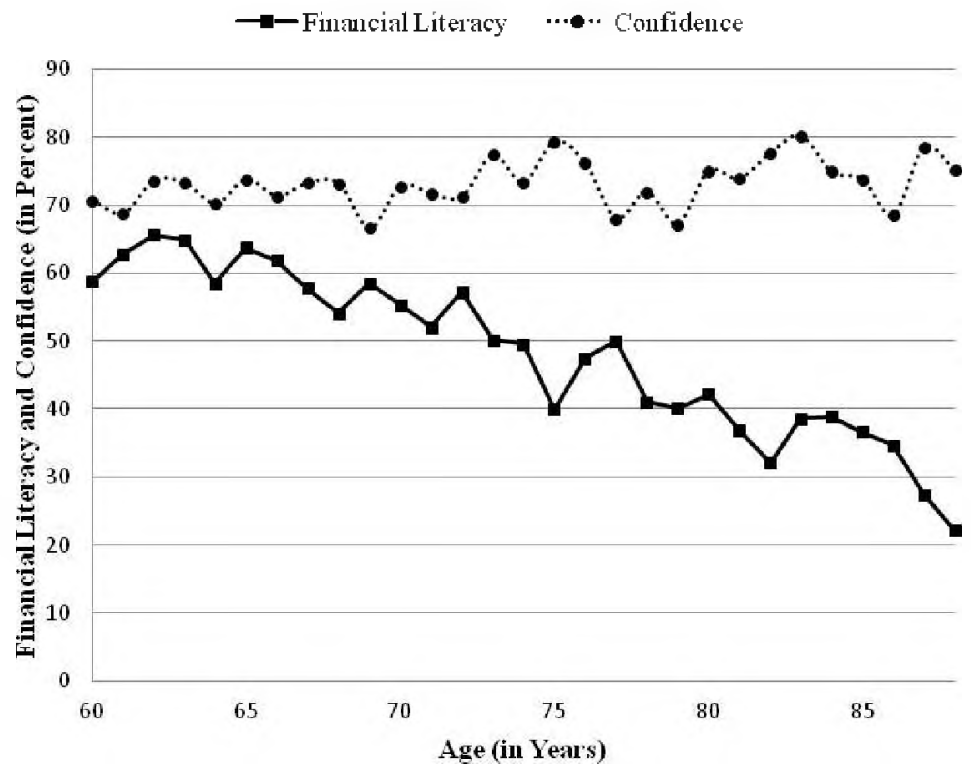

Rys. 1. Własna ocena kompetencji finansowych i obiektywna w zależności od wieku wśród osób w wieku 60-88 lat. Źródło: [Finke, Howe i Huston 2011, s. 29]

Tabela 3. Poziom wiedzy ekonomicznej Polaków w zależności od wieku

\begin{tabular}{|l|c|c|c|c|c|}
\hline \multirow{2}{*}{ Wiek } & \multicolumn{3}{|c|}{$\begin{array}{c}\text { Śdnia popraw- } \\
\text { nych odpowiedzi }\end{array}$} & \multicolumn{3}{c|}{$\begin{array}{c}\text { Odchylenie struktury demograficznej grupy } \\
\text { od struktury proby według posiadanej wiedzy } \\
\text { (w \%) }\end{array}$} \\
\cline { 2 - 6 } & liczba & w \% & niska & średnia & wy soka \\
\hline Do 34 lat & 8,7 & 43,5 & -5 & $+2 \%$ & $+3 \%$ \\
\hline 35-54 lata & 9,2 & 46,0 & $-12 \%$ & +4 & $+8 \%$ \\
\hline 55 lat i więcej & 6,3 & 31,5 & $+17 \%$ & $-5 \%$ & $-11 \%$ \\
\hline
\end{tabular}

Źródło: opracowanie własne na podstawie [Fundacja Kronenberga 2009, s. 118-119].

Porównywalne do przedstawionych powyżej badania dotyczące decyzji, kompetencji i wiedzy finansowej wśród osób starszych zostały przeprowadzone również w innych krajach. Wynika z nich, że niski poziom kompetencji finansowych jest zjawiskiem powszechnym i dotyczy również Polski. Warto przytoczyć choćby wyniki przeprowadzanych cyklicznie od $2008 \mathrm{r}$. badań dotyczących postaw polskiego społeczeństwa wobec oszczędzania oraz raportu „Stan wiedzy finansowej Polaków" [Fundacja Kronenberga 2009] ${ }^{1}$. Okazuje się, że na 20 pytań w teście

${ }^{1}$ Badanie przeprowadzone na przełomie lipca i sierpnia 2009 r. przez Pentor Research International na reprezentatywnej próbie 1502 dorosłych Polaków. 
wiedzy ekonomicznej ${ }^{2}$, liczba poprawnych odpowiedzi wynosi średnio 8,1, a tylko $18 \%$ Polaków ma dobrą wiedzę ekonomiczną (odpowiada poprawnie na co najmniej 13 pytań). Porównując wiedzę obiektywną z subiektywną jej oceną zauważa się, że wśród osób oceniających ją jako co najmniej średnią, 30\% ma w rzeczywistości wiedzę bardzo słabą. Biorąc pod uwagę wiek respondentów, krzywa wiedzy ekonomicznej $\mathrm{w}$ zależności od wieku, tak jak w przypadku przytaczanych badań Agarwal et al., przybiera kształt „ח”, natomiast pogłębione analizy pozwalają stwierdzić, że osoby z najstarszej kategorii wiekowej badania, tj. w wieku co najmniej 55 lat zdecydowanie częściej mają niższą oraz rzadziej wysoką wiedzę ekonomiczną (tab. 3).

\section{OSOBY STARSZE JAKO POTENCJALNI INWESTORZY NA RYNKU FINANSOWYM}

Posiadanie odpowiednich kompetencji finansowych przez osoby starsze jest problemem istotnym. Seniorzy stanowią bowiem, $\mathrm{z}$ racji przekształceń w strukturze demograficznej, coraz liczniejszą grupę konsumentów i potencjalnie istotnych inwestorów na rynku finansowym [Stańko 2013, s. 9-11]. Według danych GUS, renciści i emeryci są w Polsce grupami społeczno-ekonomicznymi, które wydają największą część swojego dochodu rozporządzalnego (odpowiednio na poziomie 93,2\% oraz 84,9\% w 2012 r., przy średniej dla ogółu wynoszącej 82,2\%), [Główny Urząd Statystyczny 2013, s. 47 oraz Stańko 2013, s. 9-11]. Ponadto wartość dochodu rozporządzalnego (przeznaczanego na konsumpcję, inwestycje, oszczędności) na 1 osobę $\mathrm{w}$ gospodarstwie domowym wykazuje odwrotną tendencję, niż w przypadku dochodu całkowitego. Mimo, iż przeciętne miesięczne wynagrodzenie (3 521,67 zł w 2012 r.) w gospodarce kraju jest zdecydowanie wyższe od przeciętnie pobieranej emerytury ( $2059,31 \mathrm{zt}$,), dochód rozporządzalny wśród emerytów (1 371,62 zł w 2012 r.) jest wyższy niż wśród osób pracujących $(1289,16 \mathrm{zl})$ i niż wynosi średnia dla ogółu grup społeczno-ekonomicznych (1 278,43 zł), [ZUS 2013, s. 27 i GUS 2013]. Analizy przedstawione w Diagnozie Społecznej z 2013 r. pozwalają $\mathbf{z}$ kolei przedstawić tendencje zachowań gospodarstw domowych w Polsce na rynku finansowym. W marcu 2013 r. oszczędności posiadało jedynie $40,8 \%$ respondentów, a wśród nich przeważały oszczędności stanowiące równoważność od 1-miesięcznych do 3-miesięcznych dochodów (32\% ankietowanych gospodarstw domowych). Biorąc pod uwagę wpływ wieku na szanse posiadania oszczędności przez gospodarstwa domowe, największe prawdopodobieństwo występuje w gospodarstwach domowych, gdzie jego głowa jest w wieku co najmniej 65 lat oraz w wieku 60-64. W 2013 r. prawdopodobieństwo posiadania oszczędno-

\footnotetext{
${ }^{2}$ Pytania dotyczyły takich zagadnień, jak np. budżet państwa, inflacja, inwestycje, kredyty i karty kredytowe/debetowe, trzeci filar systemu emerytalnego.
} 
ści w tych grupach było większe odpowiednio o $29 \%$ i $12 \%$ niż wśród gospodarstw z głową w wieku 45-59 lat [Czapiński i Panek 2013, s. 71].

Brakuje pogłębionych informacji o celu gromadzenia oszczędności przez gospodarstwa emerytów, jednakże z Diagnozy Społecznej 2013 wynika, że były one dokonywane przede wszystkim z myślą o rezerwie na sytuacje losowe $(70 \%)$ i jako zabezpieczenie na starość (49\%), [Czapiński i Panek 2013, s. 60-61]. Według badań Fundacji Kronenberga przy Citi Handlowym, odsetek osób niebędących z kolei jeszcze na emeryturze, a odkładających jakiekolwiek środki z myślą o niej, wynosi zaledwie 11\% [Fundacja Kronenberga 2013, s. 41]. Biorąc pod uwagę fakt, że znaczna część społeczeństwa zdaje sobie sprawę, że otrzymywana emerytura będzie niższa od dotychczas pobieranego wynagrodzenia, taki wynik jest niepokojący i sugeruje konieczność podjęcia szeroko zakrojonej akcji edukacyjno-informacyjnej w zakresie możliwych do wykorzystania mechanizmów i produktów finansowych.

\section{POZIOM WIEDZY FINANSOWEJ STARSZYCH POLAKÓW}

Niski poziom wiedzy finansowej Polaków potwierdzają także badania CBOS z 2010 i 2012 roku. Zapytani o poziom swojej wiedzy finansowej oraz znajomość możliwości oszczędzania i inwestowania na rynku finansowym, badani w większości stwierdzili, że nie mają w ogóle orientacji (44\%) lub orientacja ta jest bardzo słaba (34\%). Tylko bardzo nieliczni (3\%) ocenili swoją wiedzę finansową bardzo dobrze [CBOS 2012]. Niskiej ocenie poziomu wiedzy finansowej sprzyjał wysoki wiek- aż 55\% ankietowanych osób w wieku powyżej 55 lat zadeklarowało poczucie braku odpowiednich kompetencji finansowych. Ocena ta wydaje się w dużej mierze odpowiadać rzeczywistości - w innym $\mathrm{z}$ badań, w którym ankietowanych pytano o najlepsze sposoby gromadzenia środków na emeryturę, najwięcej wskazań odnosiło się do zakupu nieruchomości, gruntów oraz rachunków i lokat bankowych. Tylko nieliczni respondenci mogli pochwalić się znajomością produktów dedykowanych długoterminowemu oszczędzaniu, takich jak fundusze inwestycyjne i oszczędnościowe produkty ubezpieczeniowe czy też indywidualne konta emerytalne oraz pracownicze programy emerytalne [CBOS 2010].

$\mathrm{Z}$ badań CBOS wynikają także istotne wnioski co do poziomu ryzyka inwestycyjnego akceptowanego przez osoby starsze. Dla większości badanych zdecydowanie ważniejsze jest bezpieczeństwo ulokowanych środków niż osiągnięcie ponadprzeciętnego zysku [CBOS 2012]. Starszy Polak to zatem inwestor konserwatywny, który oczekuje gwarancji na poziomie co najmniej zainwestowanej kwoty i preferuje produkty proste i dobrze znane. Oczekiwania te mogą oczywiście ulec zmianie w przyszłości, gdy do grona osób starszych dołączą osoby, które dokonywały inwestycji na rynku finansowym we wcześniejszych latach życia. 


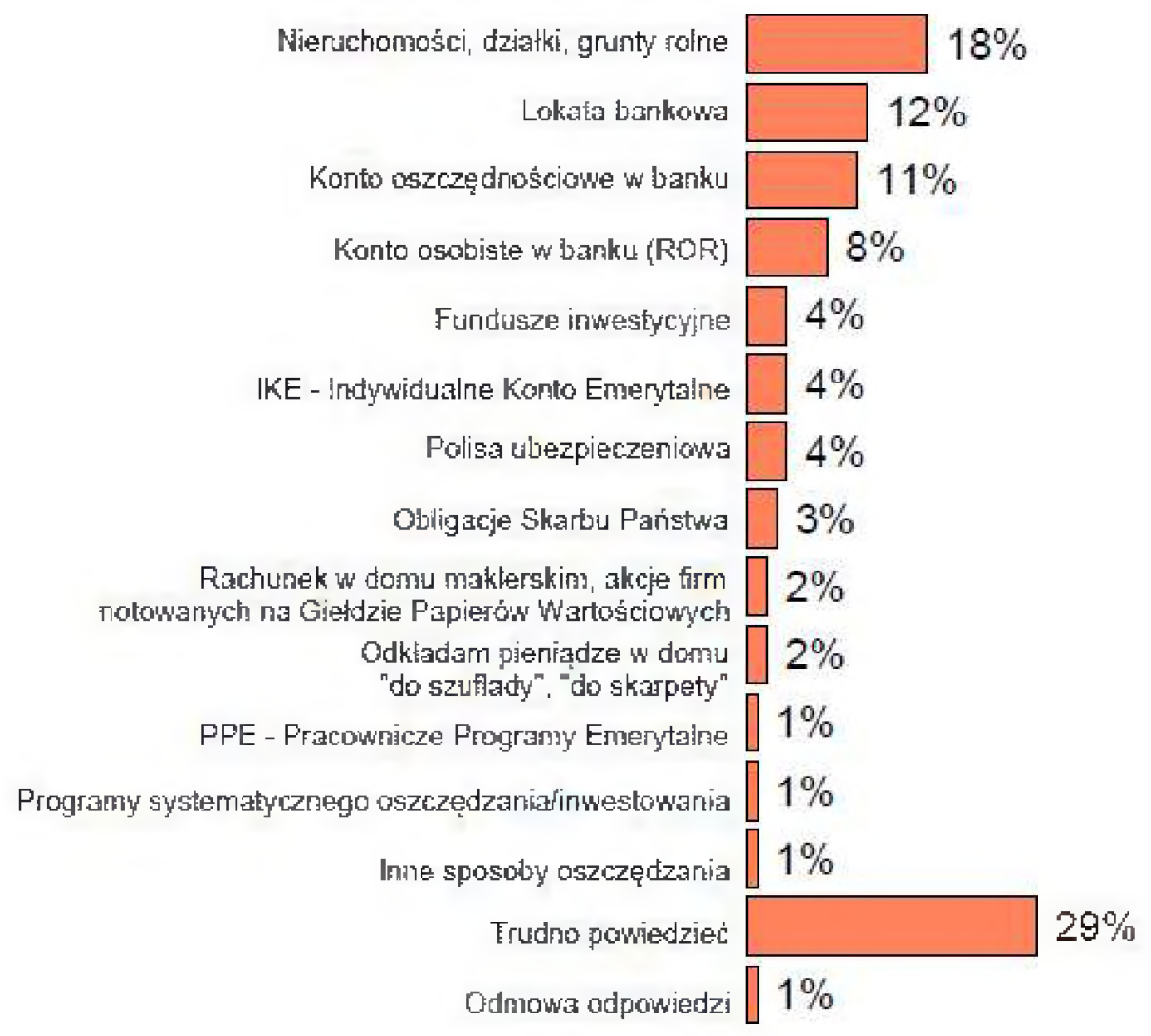

Rys. 2. Najlepsze według Polaków sposoby oszczędzania na emeryturę. Źródło: [CBOS 2010]

\section{ZAKOŃCZENIE}

Zdolności kognitywne spadają wraz $\mathrm{z}$ wiekiem. Ich obniżenie może być kompensowane wzrostem doświadczenia $\mathrm{w}$ inwestowaniu na rynku finansowym, jednak siła tego efektu zależy w dużej mierze od poziomu aktywności danej osoby na rynku finansowym we wcześniejszych latach oraz rodzajów dostępnych wówczas instrumentów finansowych. Rosnący poziom skomplikowania produktów finansowych dedykowanym obecnie gospodarstwom domowym, w tym osobom starszym, powoduje, iż tylko nieliczne jednostki są w stanie przeanalizować dostępną ofertę i wybrać propozycję najlepiej odpowiadającą ich potrzebom.

W rezultacie osoby starsze nabywają produkty nieodpowiednie lub, mając świadomość niedostatków swojej wiedzy i kompetencji finansowych, decydują się 
na wykorzystanie instrumentów dobrze znanych, takich jak rachunki i lokaty bankowe czy inwestycje w zakup nieruchomości.

Możliwości analizowania oraz oceny informacji przez osoby starsze powinny zostać uwzględnione przy konstrukcji i formułowaniu treści umów finansowych dedykowanych tej grupie konsumentów. Produkt skierowany do rosnącej rzeszy emerytów powinien być produktem prostym, przejrzystym i tanim. Aktualny konserwatyzm inwestycyjny osób starszych sugeruje, że nie powinno się wykorzystywać wyrafinowanych mechanizmów, choć te oczekiwania mogą bardzo szybko się zmieniać, gdyż kolejne pokolenia są coraz lepiej wyedukowane finansowo.

Ze względu na rosnącą liczebność, emeryci nie mogą być pomijani przy przygotowywaniu oferty usług finansowych. W przyszłości będą bowiem bardzo dużym rynkiem dla instytucji finansowych. Niepokojąco niski poziom aktualnej wiedzy i kompetencji finansowych osób starszych można podwyższyć poprzez skierowanie do tej grupy oddzielnej kampanii informacyjno-edukacyjnej, przede wszystkim w tradycyjnych mediach. Odpowiednio wysoki poziom kompetencji finansowych jest bowiem warunkiem niezbędnym do podejmowania optymalnych decyzji inwestycyjnych.

\section{LITERATURA}

Agarwal S., Driscoll J.C., Gabaix X., Laibson D.I., 2008, The Age of Reason: Financial Decisions over the Lifecycle, „NBER Working Paper”, National Bureau of Economic Research, No. 13191.

Agarwal S., Driscoll J.C., Gabaix X., Laibson D.I., 2009, The Age of Reason: Financial Decisions over the Life Cycle and Implications for Regulation, "Brookings Papers on Economic Activity", http://www.brookings.edu/ /media/ Files/Programs/ES/BPEA/ 2009 fall_bpea_papers/2009b_bpea_agarwal.pdf.

CBOS, 2010, Polacy o dodatkowym oszczędzaniu na emeryturę, komunikat $\mathrm{nr}$ BS/77/2010.

CBOS, 2012, Polak na rynku finansowym, komunikat nr BS/152/2012.

Czapiński J., Panek T. (red.), 2013, Diagnoza Spoleczna 2013. Warunki i jakość życia Polaków, J. Czapiński, T. Panek (red.), Rada Monitoringu Społecznego, Warszawa.

European Commission, 2006, The demographic future of Europe - from challenge to opportunity.

Finke M.S., Howe J., Huston S.J., 2011, Old Age and the Decline in Financial Literacy, file:///C:/Users/USER/Downloads/SSRN-id1948627.pdf.

Fundacja Kronenberga, 2013, Postawy Polaków wobec oszczędzania, Raport Fundacji Kronenberga przy Citi Handlowy, TNS Polska.

Fundacja Kronenberga, 2009, Stan wiedzy finansowej Polaków, raport Fundacji Kronenberga przy Citi Handlowy, Dom Badawczy Maison, http://www.citibank.pl/poland/ kronenberg/polish/10199.htm.

Główny Urząd Statystyczny, 2013, Budżety gospodarstw domowych w 2012 r., Główny Urząd Statystyczny, Warszawa. 
Lusardi A., 2012, Financial Literacy and Financial Decision-Making in Older Adults, http://www. asaging.org/.

OECD, 2013, Women and Financial Education: Evidence, Policy Reponses and Guidance. Samanez-Larkin G.R., 2013, Financial Decision Making and the Aging Brain, APS Obs., 26(5).

Samanez-Larkin G.R., Knutson B., 2013, Reward processing and risky decision making in the aging brain, in:. V. Reyna \& V. Zayas (Eds.) The Neuroscience of Risky Decision Making, Washington DC: American Psychological Association, http://mcablab.org/ sites/default/files/pdf/grsl13nrd.pdf.

Stańko D., 2013, Seniorzy w Polsce - perspektywa ekonomiczna, w: Osoby starsze na rynku ustug finansowych. Analiza i zalecenia, Biuletyn RPO „Zasada równego traktowania - prawo i praktyka", nr 4, Warszawa.

Xu L., Zia B, 2012, Financial Literacy Around the World. An Overview of the Evidence with Practical Suggestions for the Way Forward, Policy Research Working Paper, No 6107, The World Bank.

Zakład Ubezpieczeń Społecznych, 2013, Ważniejsze informacje z zakresu ubezpieczeń spolecznych. 2012, Warszawa.

\title{
FINANCIAL DECISIONS AND COMPETENCIES OF OLDER ADULTS FROM ECONOMIC PERSPECTIVE
}

\author{
Summary
}

Financial competence of older adults has become one of the most significant problems in the ageing world. People aged 65+ represent a huge group of consumers and potential investors on the financial markets. But financial decisions they take often do not meet their needs due to the fact that financial literacy decreases with age. Lower analitical abilities of the old and fast development of financial products are usually not balanced by aquired experience resulting in non-optimal decision-making. The research on financial literature conducted in several countries showed that the oldest citizens (people aged 60 and over) have frequently problems with assessment and comparison of financial vehicles offered by numerous institutions. Being aware of the shortage of their own financial knowledge and diminishing cognitive abilities they frequently choose products they are familiar with from the previous stages of their life 
